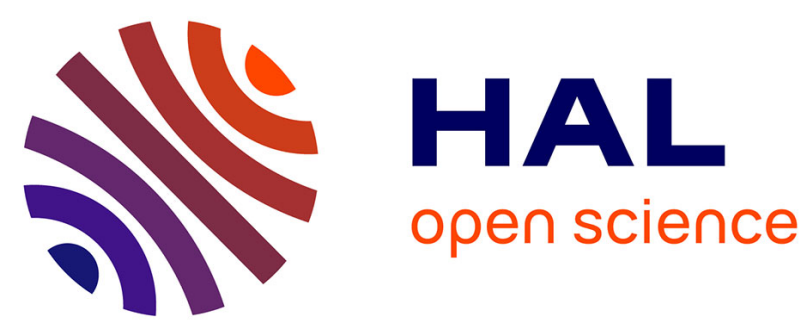

\title{
The Tropical Brown Alga Lobophora variegata (Lamouroux) Womersley: A Prospective Bioindicator for Ag Contamination in Tropical Coastal Waters
}

\author{
Marc Metian, Michel Warnau
}

\section{- To cite this version:}

Marc Metian, Michel Warnau. The Tropical Brown Alga Lobophora variegata (Lamouroux) Womersley: A Prospective Bioindicator for Ag Contamination in Tropical Coastal Waters. Bulletin of Environmental Contamination and Toxicology, 2008, 81 (5), pp.455-458. 10.1007/s00128-008-95137. hal-00540606

\author{
HAL Id: hal-00540606 \\ https://hal.science/hal-00540606
}

Submitted on 28 Nov 2010

HAL is a multi-disciplinary open access archive for the deposit and dissemination of scientific research documents, whether they are published or not. The documents may come from teaching and research institutions in France or abroad, or from public or private research centers.
L'archive ouverte pluridisciplinaire HAL, est destinée au dépôt et à la diffusion de documents scientifiques de niveau recherche, publiés ou non, émanant des établissements d'enseignement et de recherche français ou étrangers, des laboratoires publics ou privés. 
The Tropical Brown Alga Lobophora variegata (Lamouroux) Womersley: A Prospective Bioindicator for Ag Contamination in Tropical Coastal Waters

$\operatorname{Marc}_{\text {Metian }}^{1,2} \&$ Michel Warnau ${ }^{1,2}$

1 International Atomic Energy Agency - Marine Environment Laboratories, 4 Quai Antoine Ier, MC-98000 Principality of Monaco.

2 Littoral, Environnement et Sociétés (LIENSs), UMR 6250, CNRS-Université de La Rochelle, 2 rue Olympe de Gouges, F-17042 La Rochelle Cedex 01, France

Correspondence: $\quad$ Dr. Michel Warnau

LIENSs, UMR 6250, CNRS-Université de La Rochelle 2 rue Olympe de Gouges

F-17042 La Rochelle Cedex 01, France

Phone: $\quad+33662538327$

Fax: $\quad+33546458264$

E-mail: $\quad$ warnaumichel@yahoo.com 


\begin{abstract}
Uptake and depuration kinetics of dissolved silver were determined in the brown alga Lobophora variegata, using radiotracer techniques. Results indicate that this widely distributed alga could be a useful bioindicator species for surveying silver contamination in tropical environments. Indeed, results showed that the alga readily concentrates silver (algal concentration of silver was 7,000 times higher than in water after a 28-day exposure) and retains it efficiently within its tissues (biological half-life: $72 \pm 4$ days).
\end{abstract}

Key words. Silver; Bioconcentration; Coral reef ecosystems; Biomonitoring

One of the unique characteristics of silver relates to the diversity of its applications (Eisler 1996; Silver Institute 2003). On a global scale, 27,000 tons of silver are used every year (Silver Institute 2003), of which a minimum of 150 tons year ${ }^{-1}$ enters the aquatic environment from, for example, mine tailings, electroplating, or wastewater treatment plants (Silver Institute 2003).

Due to the Ag enrichment in sewage sludge from coastal cities, this metal is considered to be a good proxy for anthropogenic inputs in coastal waters (e.g., Sanudo-Wilhelmy and Flegal 1992). In addition, it has been shown both in the field and in the laboratory that several marine organisms can bioconcentrate $\mathrm{Ag}$ up to very high levels (see Ratte 1999; Metian et al. 2008). Hence, the use of Ag as a proxi for bioindicator species has been proposed as an efficient tool to survey and monitor urban contamination in the temperate coastal zones (SanudoWilhelmy and Flegal 1992; Langston and Burt 1994). According to Rainbow and Phillips (1993), extending this concept to the tropical zones, using local bioindicators, would be most useful. However, although $\mathrm{Ag}^{+}$is one of the most toxic ions to marine biota (e.g. Ratte 1999; Warnau et al. 1996b), studies on Ag dynamics in marine biota are relatively scarce and this holds particularly true for tropical environments (see e.g. Gorsuch et al. 2003).

The present work investigates Ag uptake and depuration biokinetics in the tropical brown alga Lobophora variegata, using radiotracer techniques. This species is widely distributed in the tropical zone (Coen and Tanner 1989) and is known to display quite elevated metal concentrations in the field (Hédouin et al. 2008); it is therefore a promising bioindicator species.

\title{
Materials and Methods
}

Specimens of L. variegata were collected by SCUBA diving in Maa Bay, SW lagoon of New Caledonia in October 2003. Algae were then shipped to IAEAMEL, Principality of Monaco and acclimated to laboratory conditions (constantly aerated open circuit aquarium, 20\% seawater renewal h-1; salinity 37 p.s.u.; temperature $25.0 \pm 0.5^{\circ} \mathrm{C} ; 12$-h photoperiod with a light irradiance of $300 \mathrm{lmol}$ photons $\mathrm{m}^{-2} \mathrm{~s}^{-1}$ ).

Twelve $L$. variegata thallia (average wet weight $=1.7 \pm 0.7 \mathrm{~g}$ ) were placed in a closed-circuit aquarium containing $70 \mathrm{~L}$ of natural seawater (salinity, temperature and light conditions as described above). In order to allow for 
individual recognition, each alga was placed in a cylindrical 200-mL PST container covered above and below with a 300-1m mesh net. Algae were then exposed for 28 days in seawater spiked with $0.5 \mathrm{kBq} \mathrm{L}^{-1}$ of ${ }^{110 \mathrm{~m}} \mathrm{Ag}$ (as ${ }^{110 \mathrm{~m}} \mathrm{AgNO}_{3}$; CERCA, France). Due to the specific activity of the radiotracer, this spike corresponds to an addition of $21 \mathrm{ng} \mathrm{Ag} \mathrm{L}^{-1}$, viz. a concentration that is actually found in contaminated environments (Smith and Flegal 1993). The seawater was changed and the radio- tracer spike was renewed daily to maintain ${ }^{110 \mathrm{~m}} \mathrm{Ag}$ activity constant. Radioactivity in the water was measured before and after each seawater renewal in order to determine the time-integrated radiotracer activity (Rodriguez y Baena et al. 2006). L. variegata thallia were regularly ccounted to determine the ${ }^{110 \mathrm{~m}} \mathrm{Ag}$ uptake kinetics. Radioactivity was measured using a high-resolution c-spectrometry system consisting of four coaxial Germanium (N- or P-type) detectors (EGNC 33-195-R, Canberra ${ }^{\circledR}$ and Eurysis ${ }^{\circledR}$ ) connected to a multi-channel analyzer and a computer equipped with a spectra analysis software (Interwinner ${ }^{\circledR} 6$ ). Activities of the samples were determined by comparison with standards of known activities and appropriate geometry and were corrected for background and physical decay. Counting times were adapted to obtain counting rates with relative propagated errors $<5 \%$.

Following the exposure period, all algae were transferred to new meshsided PST containers and placed in clean flowing seawater (open circuit; flux: 50 $\mathrm{L} \mathrm{h}^{-1}$; constantly aerated; salinity, temperature and light conditions as described above) for 62 days. These were then radioanalysed at different times (as described above) to determine ${ }^{110 \mathrm{~m}} \mathrm{Ag}$ depuration biokinetics.

Uptake of ${ }^{110 \mathrm{~m}} \mathrm{Ag}$ was expressed in terms of concen- tration factors (CF; viz. ratio between ${ }^{110 \mathrm{~m}} \mathrm{Ag}$ activity in alga- $\mathrm{Bq} \mathrm{g}{ }^{-1}$ wet wt-and time-integrated activity in seawater- $-\mathrm{Bq} \mathrm{g}^{-1}$ ) over time (Warnau et al. 1996a). Uptake kinetics were best fitted using the following saturation exponential equation:

$\mathrm{CF}=\mathrm{CF}_{\mathrm{ss}} \square\left(1-\mathrm{e}^{-\mathrm{k}_{\mathrm{e}} \mathrm{t}}\right)$

where $\mathrm{CF}$ and $\mathrm{CF}_{\mathrm{ss}}$ are concentration factors at time $t(\mathrm{~d})$ and at steady state, respectively, and $\mathrm{k}_{\mathrm{e}}$ is the depuration rate constant $\left(\mathrm{d}^{-1}\right)$.

Depuration of ${ }^{110 \mathrm{~m}} \mathrm{Ag}$ was expressed as decrease in percentage of remaining activity (viz., radioactivity at time $t$ divided by the initial radioactivity measured in the alga at the beginning of the depuration period * 100) over time (Warnau et al. 1996a). Depuration kinetics were best fitted using the following exponential equation:

$\mathrm{A}_{t}=\mathrm{A}_{0} \mathrm{e}^{-\mathrm{k}_{\mathrm{e}} t}$

where $A_{t}$ and $A_{0}$ are the remaining activities (\%) at time $t(d)$ and 0 , respectively, and $\mathrm{k}_{\mathrm{e}}$ is the depuration rate constant $\left(\mathrm{d}^{-1}\right)$. The biological half-life $\left(\mathrm{T}_{\mathrm{b}^{1 / 2}}\right)$ of ${ }^{110 \mathrm{~m}} \mathrm{Ag}$ in $L$. variegata was calculated according to the relation $\mathrm{T}_{\mathrm{b} / 2}=\ln 2 / \mathrm{k}_{\mathrm{e}}$ (Warnau et al. 1996a).

Constants of the models and their statistics were estimated by iterative adjustments of the model and Hessian matrix computation using the non-linear curve-fitting routines in the Statistica ${ }^{\circledR} 5.1$ software. The level of significance for statistical analyses was always set at $\alpha=0.05$.

\section{Results and Discussion}


Lobophora variegata concentrated readily ${ }^{110 \mathrm{~m}} \mathrm{Ag}$, reaching a mean concentration factor, $\mathrm{CF}$, higher than 7,000 after 28 days of exposure. Uptake biokinetics were best described by a saturation model (Fig. 1), which was characterised by an estimated steady-state $\mathrm{CF}, \mathrm{CF}_{\mathrm{ss}}$, of $12,900 \pm 2,350$ ( $\mathrm{p}<0.0001$ ).

Subsequent depuration of incorporated ${ }^{110 \mathrm{~m}} \mathrm{Ag}$ was followed over a 62-day period. Depuration kinetics were best fitted using a single exponential equation (Fig. 2), characterised by a relatively slow depuration rate constant $\left(\mathrm{k}_{\mathrm{e}}=0.0097\right.$ $\pm 0.0005 ; \mathrm{p}<0.0001)$, indicating that $\mathrm{Ag}$ was efficiently retained within the alga tissues, with a biological half-life of $72 \pm 4$ days.

Information on $\mathrm{Ag}$ bioaccumulation kinetics in macroflora representatives is scarce in the scientific literature, whether in the field or in the laboratory (Langston and Burt 1994; Warnau et al. 1996a; Boisson et al. 1997; Ratte 1999). Nevertheless, comparison with the data available from other marine macroalgae and macrophytes clearly shows the intensity of $\mathrm{Ag}$ bioaccumulation in $L$. variegata (Table 1).

Table 1 Experimental ${ }^{110 \mathrm{~m}} \mathrm{Ag}$ concentration factors $(\mathrm{CF})$ in different organisms.

\begin{tabular}{|c|c|c|}
\hline Organisms & CF & References \\
\hline $\begin{array}{c}\text { Lobophora variegata } \\
\text { (brown alga) }\end{array}$ & $1.2910^{4 \mathrm{a}}$ & present study \\
\hline $\begin{array}{l}\text { Fucus vesiculosus } \\
\text { (brown alga) }\end{array}$ & $10^{3 \mathrm{~b}}$ & Boisson et al. 1997 \\
\hline $\begin{array}{l}\text { Caulerpa taxifolia } \\
\text { (green alga) }\end{array}$ & $2.510^{2 \mathrm{c}}$ & Warnau et al. 1996 \\
\hline $\begin{array}{l}\text { Posidonia oceanica } \\
\text { (seagrass) }\end{array}$ & $1.410^{2 \mathrm{a}}$ & Warnau et al. 1996 \\
\hline $\begin{array}{l}{ }^{a} \mathrm{CF} \text { at steady state } \\
{ }^{\mathrm{b}} \mathrm{CF} \text { calculated after } 12 \mathrm{da}\end{array}$ & xposure & \\
\hline
\end{tabular}

The high CFs observed in L. variegata could result from (1) biosorption processes, where the metal in solution binds to the cell walls of the macroalgae (Schiewer and Wong 2000) and/or (2) bioconcentration and sequestration processes, where the metal enters within the cell and strongly binds to macromolecules such as polyphenols, phytochelatins and metallothioneins (Morris et al. 1999; Cobbett 2000).

According to the literature related to Ag marine geochemistry and algal bioaccumulation, the high $\mathrm{Ag} \mathrm{CF}$ observed in L. variegata is likely driven by both adsorption and cell concentration processes. It is indeed documented that charged or polar Ag compounds can be adsorbed onto algae cell surfaces, and that lipophilic, non-polar Ag chloride complexes are directly incorporated into the cells (see e.g. Ratte 1999). The high CF observed in L. variegata suggests that bioconcentration should be particularly intense compared to adsorption in this species. This is also supported by the fact that L. variegata has a high content of polyphenolic compounds (up to $13.4 \%$ on a dry weight basis; Targett 
et al. 1992), for which Ag has a high affinity. This suggests that metal bioaccumulation and chelation with phlorotannins (viz. the brown algae polyphenols) could play a major role in Ag bioaccumulation in L. variegata, as well as in the strong retention capacity shown by the alga for Ag.

Overall, our results indicate that $L$. variegata could be considered as a relevant bioindicator species for Ag contamination in tropical waters, as it shows a rapid response in metal uptake and strong retention capacity. Therefore it has the potential to provide valuable information on the contamination levels occurring in its environment. Further research is needed to verify whether phlorotannins in L. variegata could also be proposed as a sensitive biomarker of Ag contamination in seawater.

Acknowledgments The IAEA is grateful for the support provided to its Marine Environment Laboratories by the Government of the Principality of Monaco. Authors thank P. Bustamante (LIENSs) for constructive comments on the ms and J.L. Teyssié (IAEA-MEL) for technical assistance. MW is an Honorary Senior Research Associate of the National Fund for Scientific Research (NFSR, Belgium) and holds a 2008 Invited Expert position at LIENSs, supported by the Conseil Régional de Poitou-Charentes. This work was supported by the IAEA and the French PNEC Programme (Chantier Nouvelle-Calédonie).

\section{References}

Boisson F, Hutchins DA, Fowler SW, Fisher NS, Teyssié J-L (1997) Influence of temperature on the accumulation and retention of 11 radionuclides by the marine alga Fucus vesiculosus (L.). Mar Pollut Bull 35:313-321

Cobbett C (2000) Phytochelatins and their roles in heavy metal detoxification. Plant Physiol 123:825-832

Coen LD, Tanner CE (1989) Morphological variation and differential susceptibility to herbivory in the tropical brown alga Lobophora variegata. Mar Ecol Prog Ser 54:287-298

Eisler R (1996) Silver hazards to fish, wildlife and invertebrates: a synoptic review. U.S. Department of the Interior, Washington DC, USA

Gorsuch JW, Kramer JR, La Point TW (eds) (2003) Environmental transport, fate, and models: papers from environmental toxicology and chemistry, 19832002. SETAC Press, Pensacola, p 544

Hédouin L, Bustamante P, Fichez R, Warnau M (in press) The tropical brown alga Lobophora variegata as a bioindicator of mining contamination in the New Caledonian lagoon: a field transplantation study. Mar Environ Res.

Langston WJ, Burt GR (1994) Bioindicators of Ag availability in UK estuaries In: Andren AW, Bober TW (eds) Proceedings, 2nd Argentum international conference on the transport, fate and effects of silver in the environment, University of Wisconsin- Madison, WI, USA, pp 125-130

Metian M, Bustamante P, Hédouin L, Warnau M (2008) Accumulation of trace elements in the tropical scallop Comptopallium radula from coral reefs in New Caledonia. Environ Pollut 152:543-552

Morris CA, Nicolaus B, Sampson V, Harwood JL, Kille P (1999) Identification 
and characterization of a recombinant metallothionein protein from a marine alga, Fucus vesiculosus. Biochem J 338:553-560

Rainbow PS, Phillips DJH (1993) Cosmopolitan biomonitors of trace metals. Mar Pollut Bull 26:593-601

Ratte HT (1999) Bioaccumulation and toxicity of silver compounds: a review. Environ Toxicol Chem 18:89-108

Rodriguez y Baena AM, Metian M, Teyssié JL, De Broyer C, Warnau M (2006) Experimental evidence for ${ }^{234} \mathrm{Th}$ bioaccumulation in three Antarctic crustaceans: potential implications in particle flux studies. Mar Chem 100:354-365

Sanudo-Wilhelmy SA, Flegal R (1992) Anthropogenic silver in the southern California bight: a new tracer of sewage in coastal waters. Environ Sci Technol 26:2147-2151

Schiewer S, Wong MH (2000) Ionic strength effects in biosorption of metals by marine algae. Chemosphere 41:271-282

Silver Institute (2003) World silver survey. The Silver Institute, Washington DC, USA

Smith GJ, Flegal AR (1993) Silver in San Francisco Bay estuarine waters. Estuaries 16:547-558

Targett NM, Coen LC, Boettcher AA, Tanner CE (1992) Biogeographic comparisons of marine algal polyphenolics: evidence against a latitudinal trend. Oecologia 89:464-470

Warnau M, Fowler SW, Teyssié J-L (1996a) Biokinetics of selected heavy metals and radionuclides in two marine macrophytes: the seagrass Posidonia oceanica and the alga Caulerpa taxifolia. Mar Environ Res 41:343-362

Warnau M, Iaccarino M, De Biase A, Temara A, Jangoux M, Dubois P, Pagano G (1996b) Spermiotoxicity and embryotoxicity of heavy metals in the echinoid Paracentrotus lividus. Environ Toxicol Chem 15:1931-193 


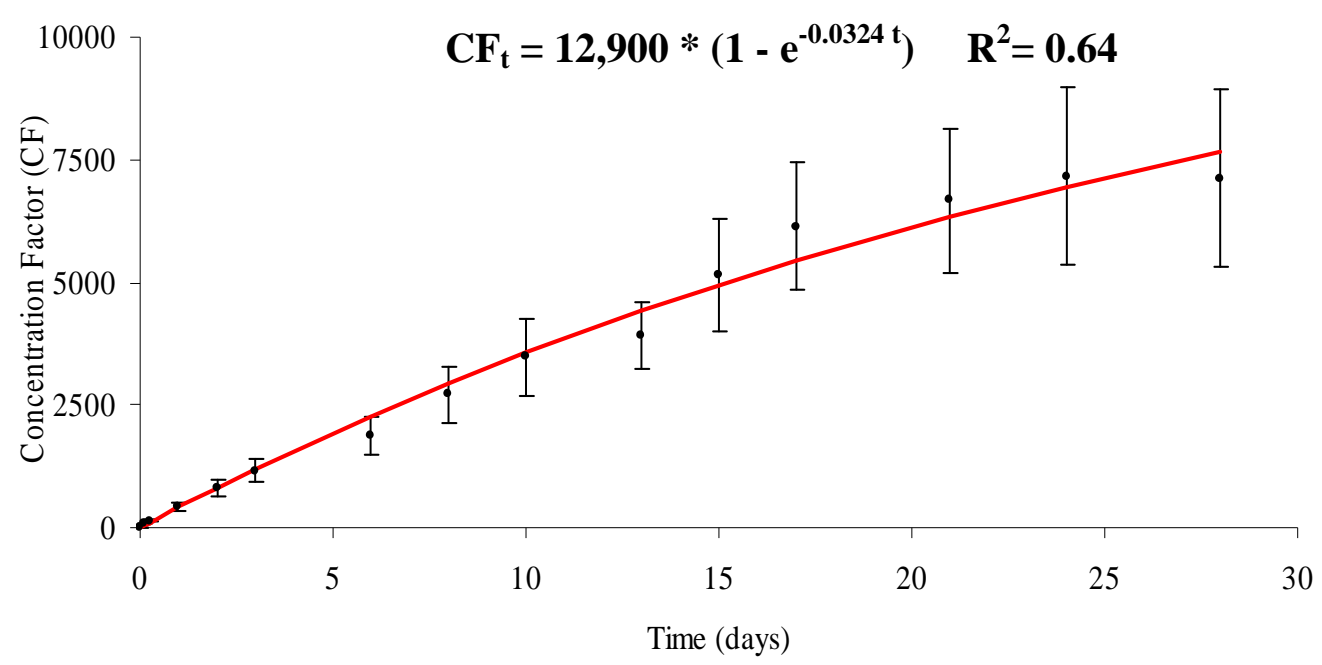

Fig. 1 Uptake kinetics of ${ }^{110 \mathrm{~m}} \mathrm{Ag}$ in Lobophora variegata (mean concentration factor $\pm S D, n=12$ ) 


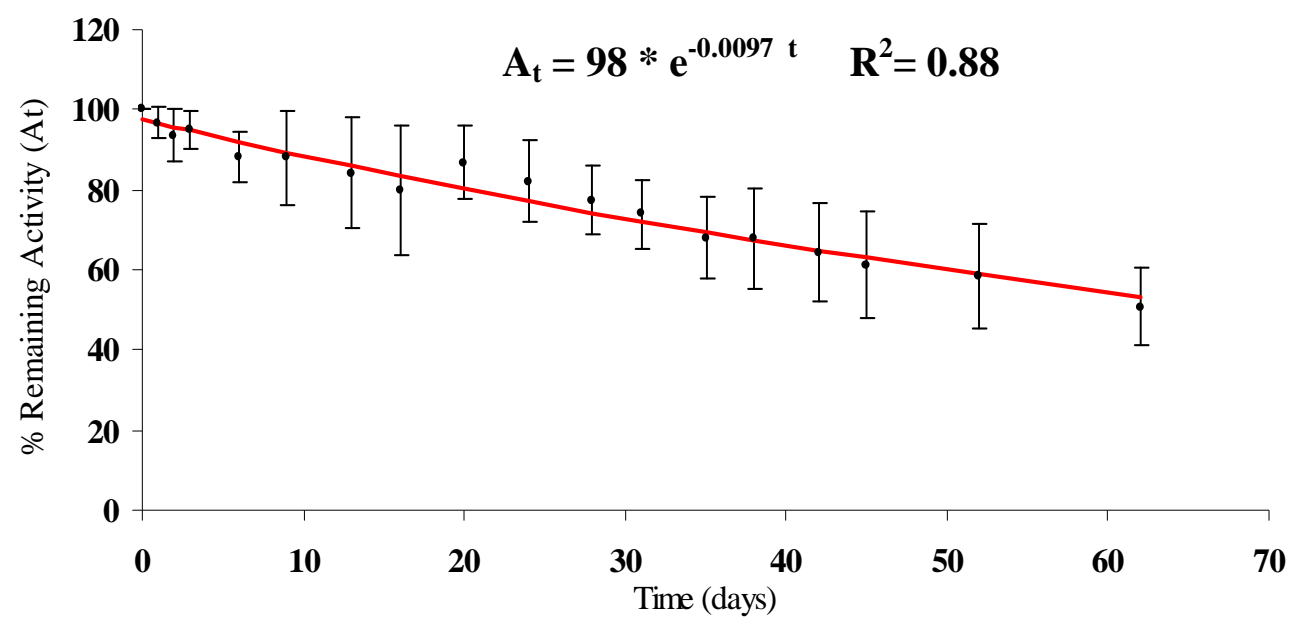

Fig. 2 Depuration kinetics of ${ }^{110 \mathrm{~m}} \mathrm{Ag}$ in Lobophora variegata (\% Remaining Activity $\pm \mathrm{SD}, \mathrm{n}=12$ ) 